\title{
АНГЛИСКИТЕ ПЕРИФРАСТИЧНИ ПРЕДИКАТИ СО ГЛАГОЛОТ ТАКЕ
}

\author{
Наташа Стојановска-Илиевска \\ Универзитет „Св. Кирил и Методиј“, Скопје \\ n.stojanovska@flf.ukim.edu.mk
}

Предмет на овој труд се англиските перифрастични предикати (ПП) со синсемантичкиот глагол (СГ) take. Овие конструкции се класифицираат во четири групи врз основа на семантички критериум, при што се дискутираат метафоричките проширувања на СГ take во сите групи. Се анализираат примери од ПП со take преземени од Британскиот национален корпус (БНК) и се дискутираат можностите кои се отвораат со употребата на ПП, наспроти соодветниот автосемантички глагол (АГ). Се истражува дали меѓу ПП со take и соодветниот АГ секогаш се воспоставува релација на синонимија, дали меѓу ПП co take и соодветниот АГ може да се воспостави видска разлика, дали и на кој начин ПП со take овозможуваат попрецизно изразување во однос на соодветниот АГ. Квалитативната анализа на собраните податоци е придружена со квантитативна анализа.

Клучни зборови: перифрастични предикати, синсемантички глаголи, одглаголски именки, метафорички проширувања 


\title{
ENGLISH LIGHT VERB CONTRUCTIONS WITH THE VERB TAKE
}

\author{
Nataša Stojanovska-Ilievska \\ Ss Cyril and Methodius University, Skopje \\ n.stojanovska@flf.ukim.edu.mk
}

This paper focuses on the English light verb constructions (LVC) with the light verb take. These are classified into four groups based on semantic criteria. In addition, the metaphorical extensions of the light verbtake are discussed in detail for each group. Examples sentences withLVCs with takeare extracted from the British National Corpus (BNC) and are then analyzed. Theexpressive possibilities of the LVCs are exploredin comparison to the corresponding lexical verbs. This paper particularly aims to discover whether a relation of synonymy can always be establishedbetween aLVC and its corresponding lexical verb, whetherLVCs with take and their corresponding lexical verbs can encode an aspectual opposition, and whether LVCs with take allow for a more precise expression compared to the corresponding lexical verbs. The qualitative analysis of the collected data is accompanied by a quantitative analysis.

Keywords: light-verb constructions, light verbs, deverbal nouns, metaphorical extensions 


\section{1 Вовед}

Предмет на овој труд се перифрастичните предикати (ПП) со англискиот синсемантички глагол (СГ) take. Во овој труд ПП се дефинираат како комбинации од синсемантички глагол (СГ) и (од)глаголска именка што е семантички блиска до концептот nomen actionis (Тополињска 1982: 36; Allerton 2002: 115). Притоа, под СГ се подразбира глагол кој е семантички сиромашен, т.е. повеќе или помалку испразнет од своето лексичко значење (Миркуловска 1991 :1), а (од)глаголската именка опфаќа не само називи на дејства (nomina actionis во потесна смисла) туку и свршени чинови (nomina $a c t i$ ) и називи на состојби (Тополињска 2003: 39). Таа претставува семантичко јадро на конструкцијата.

Поради општо присутната тенденција за номинализација на исказот, што е типична за многу европски јазици, во денешно време ПП доживуваат сѐ пораспространета употреба. Тие се присутни и во пишаните текстови (во јазикот на печатот, администрацијата, научните текстови, политичкоправните документи), но и во колоквијалниот секојдневен говор.

Со оглед на тоа што честопати се укажува на синонимија меѓу ПП и соодветните автосемантички глаголи (АГ), т.е. глаголите од кои е изведена номинализацијата во ПП, истражувањето има за цел да ја проучи мотивацијата за употребата на ПП со take. Врз основа на примерите, ќе се разгледаат следниве можности: отсуството на комплетна синонимија меѓу ПП co take и соодветниот АГ, видската разлика меѓу ПП и АГ, како и можностите за попрецизно изразување со ПП во споредба со АГ. Притоа, се разгледуваат можноста за промена на комуникациската хиерархија на аргументите, можноста за модификација на именката со придавка, можноста за квантификација на именката, и сл. Понатаму, се дискутираат и можноста за пасивизација, како и можноста за определеност на именката во ПП и се одредува во колкава мера токму тие ја мотивираат употребата на ПП. Всушност, токму поради тоа што ПП содржат две разнородни компоненти (една глаголска и една именска), со нивната употреба се отвораат можности да се искористат и глаголските и именските категории за нијансирање на значењето.

Во тој контекст, во ова истражување ќе се проверат следниве претпоставки:

1. Меѓу ПП со take и соодветниот АГ не секогаш може да се воспостави релација на синонимија.

2. Меѓу ПП со take и соодветниот АГ може да се воспостави видска разлика. 
3. ПП co take овозможуваат попрецизно изразување отколку со соодветниот АГ.

\section{2 Теориска рамка}

\section{1 Општи согледувања за ПП}

Во англиската литература, ПП се дискутираат уште во првата половина на XX век, во англиските граматики на Паутсма (Poutsma 1926), Карм (Curme 1935) и Јесперсен (Jespersen 1942). Во втората половина на XX век и почетокот на XXI век подетално со нив се занимаваат Ренски (Rensky 1964), Никел (Nickel 1968, 1978), Лајв (Live 1973), ${ }_{1}^{1}$ Вјежбицка (Wierzbicka 1982), Диксон (Dixon 2005), Стајн (Stein 1991), Бругман (Brugman 2001), Алертон (Allerton 2002), Алџио (Algeo 2006) и други лингвисти. Повеќето од нив речиси на идентичен начин зборуваат за честотата и за продуктивноста на оваа конструкција, велејќи дека постои „силна тенденција“(Curme 1935: 22), „општа тенденција“ (Jespersen 1942: 117), или „забележлива тенденција“ (Poutsma 1926: 394) да се употребуваат ПП во современиот англиски јазик.

Сепак, постојат извесни несовпаѓања во поглед на термините што различни автори ги користат за ПП, како и за типовите на конструкции кои тие ги опфаќаат со тој термин. За ПП, кои се предмет на овој труд, Паутсма го користи терминот group-verbs (Poutsma 1926: 394), а Јесперсен (Jespersen 1942: 117) не нуди назив за целата конструкција туку само го воведува терминот light verb за СГ. Освен овие, предложени се и следниве називи: вербо-номинални фрази (Ренски), комйлексни гллаг̄оли (Никел), take - have фрази (Лајв), вербо-номинални констирукции (Акимото) ${ }^{2}$ и др.

Вјежбицка (Wierzbicka 1982) за ПП го користи називот ӥерифрасииични глаголски консиирукции. Таа темелно ги проучува ПП од типот have $a V$ и заклучува дека конструкцијата е прилично колоквијална и не дозволува употреба на глаголи од висок стил во својот состав. Слично на Диксон, ${ }^{3}$ и таа смета дека компонентата од ПП која е носител на суштинската информација не е формализирана како номинализација, туку како глагол (ibid,756). Според

\footnotetext{
${ }^{1}$ Податоците за Ренски, Никел, Лајв се преземени од Brinton (1996: 186-188).

2 Податоците за Ренски, Никел, Лајв и Акимото се преземени од Brinton (1996: 186) и ги спомнувам овде за да ја илустрирам големата неусогласеност во лингвистичките кругови по ова прашање.

${ }^{3}$ Dixon (2005: 459). Тој смета дека вториот суштински елемент на ПП е глагол чија основна форма станува центар на именската синтагма, а конструкциите ги обележува како have a verb, take a verb, give a verb и сл.
} 
тоа, оваа компонента не се третира како именка конвертирана ${ }^{4}$ од глагол, а ваквиот став, секако, ги исклучува и именките морфолошки деривирани од глаголи.

За разлика од Јесперсен (Jespersen 1942), Диксон (Dixon 2005) и Вјежбицка (Wierzbicka 1982), кои ги изземаат од своите истражувања девербативните именки добиени по пат на деривациска суфиксација, повеќето лингвисти (Quirk et al. 1985), Алгео (Algeo 2006), Бругман (Brugman 2001), Алертон (Allerton 2002), и покрај тоа што го согледуваат значителното присуство на ПП со именки добиени по пат на конверзија, сепак, не ги одвојуваат едните од другите поради нивната идентична функција во ПП.

Бругман го користи терминот light verb constructions (Brugman 2001: 55154) и го заснова својот труд врз начелата на когнитивната лингвистика, како теориска подлога што ги третира семантичкиот придонес и граматичките функции на СГ како два неспротиставени аспекта кои се надоврзуваат и се надополнуваат еден со друг. Нејзиниот придонес главно се состои во тоа што таа децидно и систематски укажува на извесна воочлива семантичка нишка кај СГ, која главно води потекло од некое од значењата на истиот глагол во автосемантичка употреба.

Стајн (Stein 1991) во своето истражување се фокусира на комбинации од глаголите havel take /give и именки конвертирани од глаголи, при што е задолжителна употребата на неопределениот член a/an. Таа заклучува дека самата конструкција не генерира нови именки конвертирани од глаголи туку претходното постоење на ваква именка е предуслов таа да се јави во перифрастичната конструкција.

Алџио (Algeo 2006) за ПП го употребува терминот ӣроширени ӣреgикайи (expanded predicates) и врз основа на неговото истражување на корпуси од британски и од американски англиски јазик заклучува дека ПП се својствени за двете регионални варијанти на англискиот јазик, но дека сепак тие се позастапени во британскиот англиски јазик.

Алертон (Allerton 2002: 6) ги вбројува ПП во комплексните предикати, наспроти простите еднолексемни предикати. Под терминот stretched verb constructions, тој опфаќа шест типа на разнородни конструкции градени околу ист семантички центар.

Во овој дел беа накратко презентирани највлијателните согледувања за ПП во англистиката. На некои од овие автори се навраќам повторно во овој труд, изложувајќи ги нивните ставови во врска со ПП со take. Овие ставови ги анализирам, коментирам, дополнувам или ги поткрепувам со своите сознанија.

\footnotetext{
${ }^{4}$ Конвертирана именка претставува именка која е резултат на процесот на конверзија/нултадеривација. Според англиската традиција, конверзијата/нултата-деривација се сфаќа како премин на една лексема од една во друга зборовна група, без никаков морфолошки показател за тоа. На пр. to walk >a walk (Crystal 2008: 114).
} 


\section{2 ПП со глаголот take}

Глаголот take (зема) влегува во основниот лексички фонд на англискиот јазик. Прототипското значење на take подразбира процес во кој еден субјект со раце дофаќа/зграпчува некој релативно мал, лесен материјален предмет, при што тој предмет останува кај истиот тој субјект. По пат на метафоричко проширување ова значење се проширува и на нематеријални предмети.

Во просторно-временскиот домен, постојат сличности меѓу предикатите take и give (gaвa) во англискиот јазик, а тие се состојат во тоа што и двата предиката подразбираат движење на некој предмет во просторот (обично со користење на рацете), при што движењето е иницирано од човек и завршува во сферата на контрола на тој или на друг човек. Една од клучните разлики меѓу овие два предиката е насоката на движењето на предметот во однос на референтот претставен со субјектот. Во случајот на give движењето е насочено $\boldsymbol{o g}$ референтот претставен со подметот, додека кај глаголот take движењето е насочено кон референтот претставен со субјектот. Практично, во основното значење на take нужно е вклучено само едно лице, додека основното значење на give подразбира две лица. Но, ако се концептуализира давателот во чинот на земање (како трет партиципант), и со предикатот take би можело да се означи трансфер. Значи, со take може, но и не мора да се означи трансфер на некој конкретен или апстрактен предмет од еден човек на друг.

Во овој контекст, се чини релевантно да се објасни и разликата меѓу take и receive (йpuмa). Предикатот receive нужно подразбира постоење на давател и примател, а take има сосема поинаква динамика на силата бидејќи нужно подразбира постоење на само еден партиципант, оној кој го иницира чинот на земање, а кој е воедно и агенс и примател (иако во релации на трансфер може да се реализира и вториот партиципант - давателот). Со предикатот receive ce означува, во основа, истата релација како и со предикатот give, но кај receive таа се согледува од поинаква перспектива, односно фокусот се префрла на крајниот сегмент од чинот на давањето. Затоа и паралелно со конструкциите give one's blessing, give thanks, постојат и receive one's blessing, receive thanks, а не take one's blessing, take thanks (Newman 1996: 244). Со ова се покажува зошто take и не е секогаш најпрецизниот релациски антоним на give (Hurford and Heasley 2007: 123) туку се посочува глаголот receive како антоним на give (Allerton 2002: 189).

Во доменот на контрола, разликите во прототипските значења на предикатите give и take се одразуваат и во некои од нивните метафорички проширувања. На пример, семантиката на прототипското give подразбира дека му се дава контрола врз дадениот предмет на примателот. Од друга страна, пак, кај предикатот take, контролата над предметот ја има оној што зема и тој ниту ја предава на друго лице, ниту пак му била дадена од некого. 
Затоа, take е соодветен избор за СГ во ПП кои означуваат преземање контрола, како што ce: take control, take a lead и сл.

За прототипското значење на автосемантичкиот глагол take $\mathrm{e}$ карактеристично тоа што субјектот (C) е агенс и извор на енергијата, а трпителот (предметот чие движење е предизвикано од агенсот) се движи кон агенсот. Затоа, агенсот истовремено претставува и цел на енергијата, односно примател, како што е случајот со Џек Стоун во (1). Во истата оваа реченица се концептуализира и давателот на шолјата (сопругата на Џек), но предмет може да се да земе и директно од природата, средината и сл., а не само од некој друг човек. Оваа употреба на take не подразбира задолжително дека во релацијата има давател, или дека се реализира и чин на давање, како што се гледа од (2).

(1) Jack Stone took the mug from his wife, and sipped itgratefully. (БНК) 'Џек Стоун ја зеде шолјата од жена си и благодарно си потпивнуваше.'

(2) Bobbie took the newspaper from under her bed ... (БНК) 'Боби го зеде весникот од под креветот...'

Врз основа на оваа употреба на прототипското take, со диференцијацијата на семантичките улоги агенс и примател (Norvig and Lakoff 1987: 204-205), се овозможуваат конструкциите во кои субјектот е повторно агенс, но текот на енергијата не е насочен кон агенсот туку е ориентиран кон друго лице, т.е. кон примателот. Така, според концептуалниот модел на трансфер, во (3) агенсот е he, примателот е E. W. Fritzsch. Ваквата разлика во текот на енергијата кај овие две значења придонесува и за разлика во нивните метафорички проширувања, што доведува и до две различни синсемантички употреби на глаголот takeкај ПП.

In October he took the manuscript to Wagner's publisher, E. W. Fritzsch. (БНК)

'Во октомври тој го однесе ракописот на Вагнеровиот издавач, Е.В.Фрич.'

Бругман (2001) и Градечак-Ердељиќ (2009) предлагаат класификација на ПП co take во следниве четири групи, врз основа на метафоричките проширувања:

1. X перципира нешто преку сетилата за вид/мирис/вкус

2. Х врши дејство насочено кон себеси

3. Х врши физичко дејство насочено кон $\mathrm{Y}$

4. Х го трпи дејството извршено од $\mathrm{Y}$ 
Според Градечак-Ердељиќ (Gradečak-Erdeljić 2009), она што е заедничко за прототипското значење на take и метафоричкото проширување карактеристично за групите 1 и 2 е фактот што во двата случаи агенсот е и извор и цел на енергијата. За разлика од групите 1 и 2 , во кои не се воспоставува релација со друго лице, ПП од групите 3 и 4 означуваат релација и меѓусебно делување на 2 протагонисти. Групите 3 и 4 се разликуваат по тоа што во Групата 3 , субјектот е агенс и извор на енергија (но не и цел), додека во Групата 4 субјектот е трпен примател и цел на енергијата. Точно заради тоа, во Групата 4 се забележува најголемо оддалечување од прототипското значење на глаголот take.

Некои девербативни именки паралелно влегуваат во состав на ПП со СГ take и have. Се смета дека причината за постоењето на вакви паралелни серии на ПП со have и take се регионалните разлики, при што ПП co have ce потипични за британскиот англиски јазик, а ПП co take се карактеристични за американскиот англиски јазик.

Следува преглед на четирите групи во кои беа класифицирани ПП co take врз основа на метафоричките проширувања кои се забележуваат кај СГ take.

\section{3 Класификација на ПП co take}

\subsection{1 Група 1: X перципира нешто преку сетилата за вид/мирис/вкус}

Врз основа на прототипското значење на автосемантичкиот глагол (АГ) take, по пат на метафоричко проширување се развива значењето присутно во ПП take a taste, take a sniff, take a look, take a glance и сл. (Norwig and Lakoff 1987: 203-204). Номинализацијата во составот на овие ПП е изведена од глагол на сетилна перцепција, а метафоричкиот развој на take е според метафората 'перципирањето е примање', односно перцепцијата се поистоветува со примањето на извесни сетилни впечатоци. Според тоа, во ова метафоричко проширување субјектот останува агенс и извор на енергијата, а перципираниот објект соодветствува на трпителот во прототипското take, кој метафорички се движи кон агенсот во вид на сетилен впечаток. Затоа, агенсот, освен извор, претставува и цел на енергијата.

Некои од именките изведени од глаголи на сетилна перцепција можат да ce употребат во ПП со take, но и во ПП со give. Таков е случајот со именката $l o o k$, а нејзината употреба во два различни ПП е илустрирана во примерите (4) и (5), преземени од БНК. Од нив е јасно дека разликата во значењето меѓу овие два ПП произлегува токму од СГ, односно од особините кои СГ ги наследуваат од прототипските take и give, што апсолутно потврдува дека СГ не се сосема испразнети од значење. Затоа и текот на енергијата во примерот (4) е насочен назад кон агенсот, како и кај АГ take, односно првиот партиципант нема намера да предизвика некаква реакција кај вториот 
партиципант туку само го анализира нејзиното лице. За разлика од тоа, во (5) текот на енергијата, т.е. погледот, е насочен од првиот кон вториот партиципант со некоја цел, за да се предизвика одреден ефект кај него. Во слична насока размислува и Бругман (Brugman 2001: 569) која смета дека take a look означува насочување на перцепцијата со цел да се процесираат (асимилираат) информации, додека пак give a look јасно подразбира воспоставување на контакт очи в очи (веројатно со одреден израз на лицето) за да се постигне некаков ефект врз референтот во позиција на директен објект (ДО).

(4) Sam took a long look at her face. It conveyed nothing. (БНК)

'Сем се загледа во нејзиното лице. Тоа беше безизразно.'

He gave her a long look. I'm never wrong, Paige. (БНК)

'Тој ѝ упати еден долг поглед. Никогаш не грешам, Пејџ.'

Во овој контекст, една многу важна разлика на овие ПП во однос на АГ е тоа што агенсот на ПП свесно започнува некое дејство, менувајќи ја својата дотогашна состојба. За разлика од тоа, агенсот на АГ врши некое дејство, при што не се инсистира ниту на првичниот импулс за вршењето на тоа дејство ниту на комплетноста на дејството. Во англиските примери (6а) и (6в) може да се види како се воспоставува видска опозиција помеѓу looked и took a look, односно како за разлика од полнозначниот глагол look кој ја претставува ситуацијата како дејство, ПП take a look ја прикажува ситуацијата како остварување или како постигнување, т.е. како едно завршено дејство. Затоа и не е можна парафраза со ПП за примерот (6а), во кој глаголот изразува ателично дејство, што е неможно да се постигне со ПП (6б). Англиските примери (6а) и (6в) покажуваат дека ПП take a look може да воспостави видска опозиција со АГ look, при што ПП добива телична интерпретација.
a. Dorian looked at the picture for a long time. (БНК)
'Доријан подолго време ја гледаше сликата.'
б. *Dorian took a look at the picture for a long time.
*‘Доријан подолго време ја погледна сликата.'
в. Dorian took a look at the picture.
'Доријан ја погледна сликата.'

При анализата на ПП co take кои означуваат визуелна перцепција и соодветните АГ забележуваме дека $\mathrm{A} \Gamma$ се најчесто глаголи кои бараат дополнение во вид на предлошка синтагма (ПС) во позиција на предлошки објект (ПО), при што во ПС се среќава предлогот at. Од примерот (7б) гледаме дека ПС во позиција на ПО од конструкцијата со АГ (at the car's registration number) во идентичен облик се употребува и во конструкц+ијата со ПП (7a), но овој пат е во функција на прилошка определба за место. Од примериве 
гледаме дека, освен погоре споменатото ателично толкување (6а), АГ може да има телично толкување, како во (7б), и во таа смисла се приближува значенски кон ПП (7a). Значи, АГ look е аспектуално неутрален и дејството се интерпретира зависно од контекстот, но ПП co take се секако телични.

a. The Captain took a look at the car's registration number... (БНК) 'Капетанот ја погледна регистрацијата на автомобилот...'

б. The Captain looked at the car's registration number... 'Капетанот ја погледна регистрацијата на автомобилот...'

Глаголите што означуваат перцепција на мирис и вкус обично бараат дополнение во вид на именска синтагма (ИС) во позиција на ДО. И покрај тоа, овој аргумент практично и не е погоден од глаголското дејство. Објектниот аргумент на ваквите глаголи се акомодира кон номинализираната предикација во ПП како објектен генитив (objective genitive), т.e. како предлошка синтагма воведена со предлогот of. Според Коптјевскаја-Там (Koptjevskaja-Tamm 1993), ова отсликува една тенденција која е широко распространета во светските јазици, според која објектниот аргумент на даден глагол се адаптира кон номинализацијата преку генитивна ПС. Така, предметниот аргумент на глаголот sniff од (8б) се акомодира кон номинализацијата во ПП како објектен генитив (of $i t$ ), како што се гледа од (8a). Воедно, самата можност за акомодирање на ДО на овие глаголи кон номинализацијата во ПП преку објектен генитив потврдува дека вториот елемент во ПП е со именска природа, а не со глаголска, како што сметаат Вјежбицка (1982) и Диксон (2005).

a. She took a deep sniff of it. Heavenly! What a marvellous flower it was... (БНК)

'Таа го помириса. Боженствено! Колку прекрасен цвет беше тоа...'

б. $\quad$ She sniffed it. Heavenly! What a marvellous flower it was...

'Таа го помириса. Боженствено! Колку прекрасен цвет беше тоа...'

\subsection{2 Група 2: Х врши дејство насочено кон себеси}

Во оваа група се опфатени ПП кои во суштина означуваат непреодни дејства, и затоа номинализацијата во нив е изведена од непреоден глагол (take a walk / a swim / a stroll / a nap). Нивниот единствен задолжителен аргумент е агенсот, кој е идентичен како во конструкцијата со АГ. Слично како и кај претходната група, и за овие ПП е карактеристично движење и намерност во вршењето на дејството. Дејството изразено со ПП со take не мора да биде 
моментално туку може да трае и извесен (краток) период, како што е случај co take a swim или take a walk. Кај нив дејството се согледува како една временски ограничена целина, а присутни се и елементите одлучување, иницијатива и контрола од страна на агенсот. Овде Вјежбицка (Wierzbicka 1982: 792) согледува суптилна семантичка разлика меѓу ПП со take и have со истата девербативна именка. Имено, таа смета дека кај ПП take a walk агенсот има конкретна претстава каде ќе шета и колку долго тоа ќе трае, додека со ПП have a walk станува збор за активност која не е испланирана во поглед на времето и конкретната траекторија на прошетката.

Податоците од корпусот БНК честопати одат во прилог на оваа претпоставка, како што е случај со примерите (9) и (10). Од нив забележуваме дека кај ПП co take (9) се забележува дека агенсот планира да се движи во конкретен правец и презема дејство со конкретна цел, додека кај ПП со have (10) не се укажува на конкретна, претходно испланирана маршрута.

I finished up in Rome, home to so many of the works I lectured on, and on my last night there I took a walk down to Bernini's Trevi fountain in order to throw in the coin that would ensure that somehow I would one day return.... (БНК)

'Најнакрај отидов во Рим, дом на многу од делата за коишто држев предавања, и последната вечер таму прошетав до фонтаната Треви на Бернини за да фрлам во неа паричка со цел да се осигурам дека еден ден пак ќе се вратам во Рим.'

(10) So we had a walk round town. (БНК)

'Па така, се прошетавме низ градот.'

И од други примери од БНК гледаме дека кај ПП со take најчесто (но не секогаш) се среќава прецизна информација во врска со местото каде што се врши дејството (took a stroll down to the City Hospital, took a dip in a small pool и др.). Би можело да се заклучи дека со ПП од оваа група се означуваат дејства на движење, обично по испланирана траекторија, кои се преземени по иницијатива на агенсот и кои претставуваат временски ограничени (краткотрајни) целини.

\subsection{3 Група 3: X врши физичко дејство насочено кон Y}

Кај ПП од оваа група (take a stab / punch/ kick) она што е преземено од динамиката на силата карактеристична за прототипското take е тоа што субјектот е агенс и извор на енергија (иницијатор на дејството). Метафоричкото проширување се состои во тоа што упатувањето на едно брзо силно движење од агенсот кон планираниот примател во ПП се поистоветува 
со пренесувањето на некој предмет од агенсот кон примателот кај АГ take (Norwig and Lakoff 1987: 201). Во ваквите случаи во ПП е типична употребата на at наместо to (како кај прототипското take). Со ова се укажува на тоа дека co ПП co take целта не мора задолжително да биде постигната, т.е. со ударот може, но и не мора да се погоди целта (11a), за разлика од прототипското take каде што предметот секако завршува на планираната дестинација. Значи, со овие ПП се означува упатување на удар без да се инсистира на тоа дали е целта постигната или не, и затоа тие претставуваат еден вид на конативни конструкции, кои прилегаат на употребата на АГ punch и kick co предлогот at (11в) за да се изрази истото значење. Ваквите конативни конструкции се разликуваат семантички и синтаксички од монотранзитивните конструкции (11б). Семантички, со монотранзитивните конструкции се изразува и поголема погоденост на ДО од глаголското дејство, бидејќи во нив ударот секогаш завршува во планираната цел. Синтаксички, аргументот од позиција ДО во монотранзитивните конструкции (11б) се реализира како ПС со at во конативните конструкции $(11 \mathrm{~B}, 11 \mathrm{a})$. Всушност, како што станува збор за конативна алтернација меѓу примерите (11б) и (11в), така може да се каже дека слична појава е илустрирана меѓу ПП (11a) и (11г). ПП во (11а) има блискозначна структура со АГ во (11в), а постоењето на ПП се чини дека делумно е мотивирано од непреодноста на (11в) и притисокот на морфосинтаксичкиот систем за транзитивни конструкции со структура субјект + глагол + објект. Истовремено, од споредбата на (11в) и (11a), како и на (11б) и (11г), произлегува дека ПП може да се сметаат за стратегија за синтаксичко зголемување на бројот на аргументите преку когнитивниот модел за трансфер, бидејќ́ двоаргументските предикати (11б и 11в) се концептуализираат како троаргументски предикати во ПП (11а и 11г).

(11) a. Sandy took a punch / kick at Cameron. (Brugman 2001: 567)

'Сенди замавна со тупаницата / ногата накај Камерон.'

б. Sandy punched/kicked Cameron.

'Сенди го удри со тупаница / го клоцна Камерон.'

в. Sandy punched /kicked at Cameron.

'Сенди замавна со тупаницата / ногата накај Камерон.'

г. Sandy gave Cameron a punch / kick.

'Сенди му удри бокс / клоца на Камерон.'

Освен примерот (12), во БНК не беа пронајдени примери за ПП со take од оваа група. Наместо тоа, се среќаваат перифрастични изрази како: aim a punch at, swing a punch at, throw a punch at, aim a kick at и сл.

(12) His partner is writhing on the ground, about to rise. I take a kick at him. 'Неговиот партнер се превиткува на земја, спремајќи се да се подигне. Јас замавнувам со ногата кон него.' 


\subsection{4 Група 4: X го трпи дејството извршено од $\mathrm{Y}$}

ПП од Група 4 (take a hit / take a beating) се во тесна врска со ПП од Група 3. Во основа, разликата меѓу нив се состои во тоа што кај Група 4 се профилира резултатот од дејството, односно ударот задолжително ја постигнува целта. Освен тоа, евидентна е и синтаксичка промена, така што кај ПП од Група 4 примателот ја зафаќа субјектната позиција, додека во Група 3 субјектот е агенс, т.е. вршител на дејството.

Ова најдобро се разјаснува со примерите во кои една иста номинализација влегува во состав на два различни ПП со take (едниот од Група 3, а другиот од Група 4), како што е тоа punch. Ова се поткрепува со примерите (13a) и (13б), при што во (13а) субјектот е агенс а во (13б) субјектот е трпен примател (Brugman 2001: 567).
a. Sandy took a punch at Cameron.
'Сенди замавна со тупаницата накај Камерон.'
б. Sandy took a punch from Cameron.
'Сенди прими удар со тупаница од Камерон.'

ПП од Група 4 означуваат тек на енергија кон лицето-примател, а изворот на енергија е честопати неопределен. Притоа, она што субјектот го прима не е материјален предмет туку физичка енергија. Во оваа група се вбројуваат повеќе изрази кои се пример за лексичка пасивизација, како што ce take a beating, take a knock, take a punch, take a battering и сл. Ова практично значи дека ваквите ПП имаат пасивно значење (14a), како и блискозначна парафраза со АГ во пасивна дијатеза (14б), но самите ПП се во активна дијатеза. Во овие два примера субјектот е трпен примател бидејќи физичкиот удар го сфаќаме како енергија која е упатена од Џон, а која Пол ја прима. Што се однесува на АГ во активна дијатеза (14в), и со него може да се изрази истата релација, но со поинаква комуникативна хиерархија на аргументите.
a. Paul took a kick from John. 'Пол прими клоца од Џон.'
б. Paul was kicked by John. 'Пол беше клоцнат од Џон.'
B. John kicked Paul. 'Џон го клоцна Пол.'
г. John gave a kick to Paul. 'Џон му удри клоца на Пол.'

Според Њумен (Newman 1996: 244-45), кај овие ПП со take станува збор за истата релација како и кај give a kick и give a beating, но таа се согледува од две различни перспективи. Така, во (14a) оваа релација се согледува низ 
призмата на примателот, т.е. примателот е комуникациски поважен, а во (14г) низ призмата на агенсот.

Како примери за лексичка пасивизација, ПП од оваа група се погодни јазични средства кога агенсот е нерелевантен, непознат или воопштен (15a). Наспроти тоа, употребата на глаголот во активна дијатеза го налага наведувањето на агенсот (15б).

\section{a. $\quad$ Central defenders Gary Bennett and Anton Rogan both took knocks at Grimsby... (БНК)}

'Одбранбените играчи од средниот ред Гари Бенет и Антон Роган примија удари на Гримзби.'

б. [Someone] knocked central defenders Gary Bennett and Anton Rogan at Grimsby.

'Некој ги удри одбранбените играчи од средниот ред Гари Бенет и Антон Роган.'

Во случаите, пак, кога се наведува изворот на енергијата, тој може да биде со семантичка улога на агенс, како во (14a), но и инструмент, како што е $a$

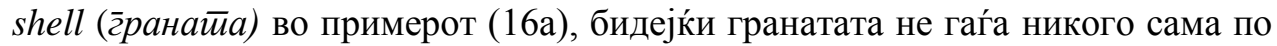
себе, туку е контролирана и управувана од некое човечко суштество. Во овој случај е можна парафраза со АГ во пасивна дијатеза (16б), при што трпниот примател останува во позиција на субјект. Освен тоа, можна е и парафраза со АГ во активна дијатеза (16в), со инструментот во позиција на субјект, а трпниот примател во позиција на ДО.

(16) a. As Lambert watched, one SE5a took a hit from a shell... (БНК) 'Додека Ламберт гледаше, еден авион SE5a беше погоден од граната...’

6. As Lambert watched, one SE5a was hit by a shell... 'Додека Ламберт гледаше, еден авион SE5а беше погоден од граната...'

в. $\quad$ As Lambert watched, a shell hit one SE5a...

'Додека Ламберт гледаше, граната погоди еден авион SE5a.. .'

Во примерите од БНК, кај примерите со ПП од оваа група, се забележа во повеќе наврати дека ниту изворот, ниту примателот на физичката енергија не мора да е човек. Изворот на физичката енергија може да е и некоја природна непогода (бури, силни ветришта и сл.) со семантичка улога каузайор, како во (17), додека пак примател на физичката енергија, во таквите случаи се домовите, населбите, индустријата итн. Притоа номинализацијата во ПП, на пр. battering во (17), добива фигуративно значење на опустошување, разрушување, наспроти буквалното значење на battering - удирање, тепање.

His home state of Florida took a battering from Hurricane Andrew. 
'Неговата држава, Флорида, беше опустошена од ураганот Ендрју.'

\section{3 Методолошки пристап}

Ова истражување се базира на Британскиот национален корпус (БНК), кој претставува жанровски избалансиран, јавно достапен електронски корпус од изворни текстови на британски англиски јазик, содржи околу 100 милиони збора и е временски ограничен на периодот помеѓу 1980-1993 година. Содржината на овој корпус е рамномерно распределена помеѓу повеќе категории: говорен јазик, проза, популарни списанија, весници, академски текстови и друго.

Во истражувањето беа преземени следните чекори: избор на ПП кои ќе се пребаруваат, пребарување на ПП во корпусот, квантитативна обработка на податоците и најнакрај, квалитативна анализа на добиените податоци. При селекцијата на пребаруваните англиски ПП главно беа користени Комбинаторниот речник на Бенсон, Бенсон и Илсон (BBI Combinatory Dictionary) и речниците на колокации: Oxford Collocations Dictionary for Students of English и LTP Dictionary of Selected Collocations. Распределбата на ПП co take во групи се базира на класификацијата користена во истражувањата на Бругман (Brugman 2001) и Градечак-Ердељиќ (GradečakErdeljić 2009). Во однос на метафоричките проширувања на глаголот take, делумно се потпирам на мислењата на Норвиг и Лејкоф (Norvig and Lakoff 1987) и Њумен (Newman 1996).

\section{4 Резултати од истражувањето}

\section{1 Дискусија на истражувачките прашања}

Преку анализа на примери од БНК се осврнувам на следниве истражувачки прашања: дали меѓу ПП со take и соодветниот АГ секогаш се воспоставува релација на синонимија, дали и во кои ситуации може да се воспостави видска разлика меѓу ПП со take и соодветниот АГ, и дали и на кој начин ПП co take овозможуваат попрецизно изразување отколку со соодветните АГ.

\subsection{1 Синонимија меѓу ПП co take и соодветниот АГ}

Истражувањето покажа дека не секогаш меѓу ПП со take и соодветниот АГ може да се воспостави релација на синонимија. Иако номинализацијата во ПП 
е изведена од глагол, во одредени случаи, од различни причини, се забележува отсуство на целосна синонимија меѓу ПП и истиот тој глагол.

Во примерот (18) гледаме дека ПП и АГ се блискозначни, но не можеме да кажеме дека се апсолутни синоними, особено заради инсистирањето на повлекувањето на само еден дим со ПП take a puff во (18a), и неопределеноста во тој поглед на глаголот puff во (18б). Генерално, ова е и најчестата причина за отсуство на целосна синонимија меѓу ПП со take и соодветните АГ (на пример, кај паровите take a gulp / gulp; take a sip/ sip; take a peep / peep; take a swig / swig; take a nibble / nibble и сл.). Воедно, забележуваме дека модификацијата на именката puff со придавката long во ПП (18a) не може адекватно да се претстави во конструкцијата со глаголот puff (18б). Додавањето на прилошката определба for a long time во (18в) не подразбира дека бил повлечен еден долг дим, туку дека биле повлечени неопределен број на димови и процесот траел подолго време, што е различно од значењето на примерот (18a). Значи, перифрастичното структурирање на предикатот овозможува попрецизно изразување преку фокусирање на предикативна содржина, со истовремено искористување на предностите достапни само на именките, а тоа се квантификацијата и придавската модификација.

a. He took a long puff on his beautiful cigar... (БНК)

'Тој повлече еден долг дим од прекрасната пура ...'

б. He puffed on his beautiful cigar...

в. He puffed on his beautiful cigar for a long time...

Отсуството на синонимија е уште повпечатливо ако самата номинализација од ПП развила и значење кое не е присутно кај АГ, како што е случај со примерот (19). Именката dip во (19a) означува краткотрајно пливање, но глаголот dip сам по себе не може да го изрази ова конкретно

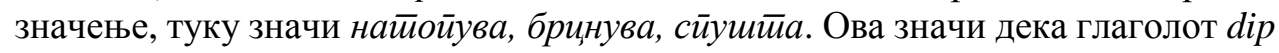
во (19б) не може да го пренесе истото значење како ПП take a dip. Единствено со додавање на прилошката определба за место in the pool/sea/ocean како дополнение на глаголот dip може да се добие приближно исто значење, како што се гледа во (19в):

(19) a. A 2 minute walk takes you down to Sandaway beach privately owned by us where children can play and explore the rock pools whilst mum and dad take a dip or laze in the sun. (БНК)

'На само две минути одење пеш се наоѓа плажата Сендавеј која е во наша приватна сопственост и каде што децата можат да си поиграат во базените, додека мама и тато пливаат или одмораат на сонцето.'

б. ... whilst mum and dad *dip or laze in the sun.

в. ... whilst mum and dad dip in the pool/sea/ocean or laze in the sun. 
Разликата помеѓу ПП take a break и глаголот break е очигледна од следните примери. ПП take a break значи йрави йауза (20a), додека глаголот break може само со конкретно дополнение да ја изрази истата идеја, како во (20б), каде што предлошката синтагма for lunch е задолжително дополнение на глаголот. Меѓутоа, во примерот (21) не е возможна замена на ПП take a break од (21a) само со глаголот break во (21б) бидејќи без соодветно дополнение на глаголот break, мислата во (21б) е нелогична. За разлика од тоа, во (21а) мислата е компактно формулирана и комплетна, а од контекстот добиваме информации за каква пауза се работи.

(20) a. We took a break for lunch at $12 \mathrm{pm}$. (БНК) 'Направивме пауза за ручек во 12 часот.'

б. We broke for lunch at $12 \mathrm{pm}$. 'Направивме пауза за ручек во 12 часот.'

(21) a. But there was a period when he tired of fashion. In 1964 he decided he wanted to go back and finish school, so he took a break. (БНК) 'Но имаше еден период кога му се смачи од модата. Во 1964 тој одлучи дека сака да го заврши училиштето, па затоа направи пауза.'

б. $\quad . .$. In 1964 he decided he wanted to go back and finish school, so he *ьвгке.

Понекогаш глаголското дејство од АГ се транспонира во номинализацијата со поголема конкретизација, т.е. како објект или како резултат на дејството. Ваквите именки честопати се користат и како термини востановени во административно-правната практика. Таков е случајот со именката decision во примерот (22a), каде што станува збор за донесување на официјална одлука (за која веројатно постоел и писмен документ). За разлика од тоа, глаголот decide (22б) е својствен и за секојдневната комуникација и има многу поширока сфера на употреба. Во таа смисла, колку и да се блискозначни (22а) и (22б), сепак, меѓу нив не може да се воспостави релација на апсолутна синонимија, а употребата на едната или на другата конструкција зависи од дадениот контекст.

(22) a. ...in March 1926 the Comintern took a decision to entrust the Communist party of the United States with special responsibility... (БНК)

‘...во март 1926 Коминтерната донесе одлука да ѝ довери посебна одговорност на Комунистичката партија на Соединетите Држави...’

б. .... in March 1926 the Comintern decided to entrust ...

'...во март 1926 Коминтерната одлучи да ѝ довери...' 


\subsection{2 Видска опозиција помеѓ ПП co take и соодветниот АГ}

Примерите од БНК покажуваат дека за видска опозиција може да стане збор првенствено кога ПП се употребуваат во простото минато време за да означат краткотрајни еднократни дејства што се случиле во одреден момент во минатото, како во (23a). За да се долови тоа значење посебно придонесува и фактот што номинализацијата во состав на ПП е именка на која ѝ претходи неопределениот член. На тој начин, дејството се претставува не како процес туку како една целина со свој почеток и крај.
a. $\quad$ She took a sip of coffee. (БНК)
'Таа пивна една голтка од кафето.'
б. She sipped her tea. (БНК)
'Таа пивна од чајот. / Таа потпивнуваше од чајот.'
в. Charlie ...sipped slowly to be sure that the simple pleasure lasted. (БНК)
'Чарли ... си потпивнуваше полека, за да се осигура дека едноставното задоволство ќе потрае.'
г. $\quad$ Irene nodded, and sipped her coffee. (БНК)
'Ајрин кимна со главата и пивна од кафето.'

За разлика од ПП take a sip, примерот со глаголот sip во (23б) може да се интерпретира и како еднократно завршено дејство и како процес што траел подолго време бидејќи не е даден контекст. Која ќе биде соодветната интерпретација на глаголот sip во голема мера зависи од контекстот, како што се гледа и од примерите (23в) и (23г). Во (23в) станува збор за процес што траел, додека пак во (23г) се работи за второто од две краткотрајни дејства што се случиле едноподруго во минатото. Видска опозиција може да се воспостави помеѓу ПП take a sip и глаголот sip единствено кога ПП take a sip означува краткотрајно дејство што се завршило во минатото, а дејството означено со глаголот sip се прикажува во своето одвивање, како во (23в). На тој начин, наспроти неограниченоста на траењето карактеристична за глаголот sip, ПП станува експонент на теличност, со тоа што го „вметнува“ елементот на крајна точка на ситуацијата, односно ја прикажува ситуацијата како едно завршено дејство.

Сосема е поинаква ситуацијата кога ПП се појавува во простото минато време со хабитуална употреба (Quirk et al. 1985: 186), како во примерот (24). Од споредбата на (24a) и (24б) може да се види дека ПП се изедначува со АГ во поглед на аспектуалното толкување, што значи дека при неактуелизираната употреба на простото минато време не се воспоставува видска опозиција. 
a. On fine evenings in summer, we always took a walk after church... (БНК)

'Кога летните вечери беа пријатни, секогаш се шетавме по одењето в црква...'

б. $\quad$ On fine evenings in summer, we always walked after church...

'Кога летните вечери беа пријатни, секогаш пешачевме по одењето в црква...'

Инхоативната компонента е доминантна кај многу ПП со take, односно со нив се нагласува почетниот импулс кој доведува до дадена состојба. Така, глаголот dislike означува чувство кое трае, но ПП take a dislike ја вклучува почетната точка на тоа чувство, што се засилува со придавката instant (25a), и што се потврдува и со парафразата (25б). Воедно, токму заради фокусот на почетокот на дејството во ПП take a lead, take control, take a dislike, во ваквите случаи не постои апсолутна синонимија помеѓу ПП и АГ бидејќи ПП take a lead, take control, take a dislike не значат само lead, control, dislike туку start to lead, start to control, start to dislike.

a. And to make matters worse I took an instant dislike to the wife. (БНК)

'За да биде уште полошо, жената веднаш ми стана антипатична.'

б. And to make matters worse I instantly started to dislike the wife.

\subsection{3 Попрецизно изразување со ПП со take отколку со соодветниот $\mathrm{AT}$}

Номинализацијата во склоп на ПП дозволува придавска модификација, како што се гледа од повеќе примери во трудот (took an instant dislike, took a long puff, took a deep sniff и сл.). Понекогаш, авторот има избор дали да употреби ваква перифрастична конструкција или конструкција со АГ и прилошка определба. На пример, за следниве примери на ПП од БНК: took a close look, took a firm grip, took a bad fall, took a different approach, took a conscious decision постојат блискозначни паралели со АГ: looked closely, gripped firmly, fell badly, approached something differently, consciously decided. Но, понекогаш изборот на придавката е таков што е тешко изводлива или речиси невозможна компактна синонимна паралела со АГ, како што беше случајот со took a long puff во (18a). Еве уште неколку примери од БНК за придавска модификација на именката во ПП, за кои е тешко да се даде компактна парафраза со АГ: took a big bite, took a large gulp, took a tiny sip, took a little walk, took a fresh look, took a new approach и др. Се забележува дека во ваквите примери честопати се употребуваат придавки што означуваат димензии (huge, large, big, small, 
tiny и др.) или опозицијата cīapo - ново (new, old, fresh (со значење new)), односно главно се работи за статични придавки. Токму ова е една од причините за претпочитањето на перифрастичните конструкции во одредени ситуации.

Номинализациите што означуваат дејство се во основа апстрактни именки. Кај нив категоријата број станува релевантна кога со нив се означуваат поединечни етапи од одредено дејство, односно кога овие именки означуваат одделни единици на временската оска, заради што има потреба да се направи разлика меѓу еднина и множина. Можноста за квантификација на именката во ПП е уште една предност која ја мотивира употребата на ПП. Така, со ПП може да се потенцира дека бил завршен само еден сегмент од некое дејство, како што се гледа од следниве примери од БНК: take a sip, take a look, take a dip, take a glimpse, take a puff, take a peep, take a bite и др. Од друга страна, со употребата на неопределена именка во множина во состав на ПП потенцираме дека биле завршени неопределен број на сегменти од некое дејство, како во (26). Меѓутоа, преку ПП може да се нагласи и точниот број на единици од дадено дејство што биле завршени, и во таквите случаи се употребува квантификатор пред множинската форма на именката, како во (27) и (28). Во ваквите случаи, авторите употребуваат номинализации за да истакнат примарно глаголска содржина, сакајќи токму на тие елементи да им дадат поголема комуникациска тежина.

(26) I took sips of my wine and carried on with the supper...(БНК)

'Си пивнав неколку голтки од виното и продолжив со вечерата...'

He took four strides to the corner...(БНК)

'Тој направи четири чекори кон аголот...'

... Gunn coped well and the absence of the Sudbury' keeper, who took two heavy knocks in the opening exchanges, made little material difference to the pattern of the game. (БНК)

'Ган добро се справуваше и отсуството на голманот на Садбери, кој прими два потешки удари на самиот почеток, не направи голема разлика во текот на мечот.'

Особено се важни и можностите за различна хиерархизација на аргументите кои се достапни во конструкциите со ПП. Ова е во тесна врска со информациската структура на реченицата. Имено, оние партиципанти кои се познати од контекстот се тематизираат (стануваат теми во субјектна позиција), а оние кои се нови, се поместуваат кон крајот на реченицата, каде што е и информациското тежиште на реченицата. Комуникацискиот фокус во ПП е на номиналниот еквивалент на глаголот, којшто претставува нов елемент во дискурсот, т.е. рема. Во примерот (29a) тоа е именката decision. Во парафразата (29б) е употребен непреодно глаголот decide. Во англискиот 
јазик вообичаено не се очекува од глаголот да е носител на максималниот комуникациски динамизам ${ }^{5}$ во реченицата туку само да претставува премин помеѓу ниското ниво на комуникациски динамизам на темата и високото ниво на комуникациски динамизам на ремата (Quirk et al. 1985: 1401). Заради тоа, ПП отвора простор да се развлече предикатот и на тој начин да се избегнат простите непреодни структури (Quirk et al. 1985: 751, 1401), а воедно овозможува да се истакне примарно глаголска содржина, која во ПП се изразува преку девербативна именка во позиција на ДО. Исто така, речениците во кои се употребува непреоден полнозначен глагол не се доследни на немаркираниот збороред СГО (субјект - глагол - објект) во англискиот јазик, па затоа постоењето на ПП може да се протолкува и како начин за вклопување на непреодните структури во доминантниот модел СГО, бидејќ и во нив се развлекува предикацијата на два составни дела: глаголски дел претставен од СГ и именски дел во позиција на објект, резервиран за номинализацијата изведена од непреодниот глагол.

a. The waiter arrived with the red wine they had ordered, and Loretta took a decision.(БНК)

'Келнерот пристигна со црвеното вино што го беа порачале и Лорета донесе одлука.'

б. The waiter arrived with the red wine they had ordered, and Loretta decided.

'Келнерот пристигна со црвеното вино што го беа порачале и Лорета одлучи.'

ПП нудат можност за редукција на бројот на површински присутните аргументи, што честопати е недозволиво кај АГ. За разлика од некои глаголи кои бараат задолжително да се наведе нивниот пропозиционален аргумент, ПП дозволуваат да се редуцира пропозиционалниот аргумент кога неговата содржина може да се реконструира од контекстот или кога таа е нерелевантна или непозната. Ова нивно својство придонесува да се претпочитаат ПП кога говорителот од некоја од горенаведените причини не сака да го наведе пропозиционалниот аргумент. Примерот (30а) ја илустрира редукцијата на пропозиционалниот аргумент, а од (30б) се гледа дека парафразата е граматички неточна без експлицитно наведување на пропозиционалниот аргумент.

(30) a. ... but finally, in 1989, the government took a decision which was considered unthinkable only a year earlier... (БНК)

\footnotetext{
5 Терминот комуникациски gинамизам се однесува на различната комуникациска вредност на одредени делови на исказот (Quirk et al. 1985: 1356).
} 
'... но конечно, во 1989, владата донесе одлука што беше незамислива пред една година...’

б. ...but finally, in 1989, the government *decided...., which was considered unthinkable only a year earlier...

Земајќи го предвид сево ова, би можело да се каже дека, врз основа на анализата на примерите од БНК, мотивацијата за употребата на ПП co take навистина и треба да се бара меѓу следниве причини: отсуството на комплетна синонимија меѓу ПП со take и соодветниот АГ, можноста за воспоставување на видска разлика меѓу ПП и АГ, можноста за модификација на именката со придавка, можноста за квантификација на именката, и сл.

\section{2 Синтаксички карактеристики на ПП co take}

Во овој дел се осврнувам на синтаксичките карактеристики на ПП кои ја мотивираат употребата на ПП. Некои од ПП co take подлежат на пасивизација, а други пак, не ја дозволуваат. Во пасивна дијатеза главно се појавуваат ПП во кои номинализацијата е во поголема мера апстрахирана од глаголското дејство (т.е. не означува процес) и е лексикализирана, како во take a decision. Во оние ПП каде пасивизацијата не е дозволена, тоа се должи и на десемантизацијата на СГ и неговата граматикализација во маркер за инхоативност (на пр. take a dislike / *a dislike was taken). Меѓутоа, ПП од Група 4, т.е. оние ПП кои се примери за лексичка пасивизација разбирливо не ја дозволуваат синтаксичката пасивизација од неколку причини. Прво, со синтаксичката пасивизација трпителот од позиција на ДО во активната реченица се авансира во позиција на субјект на пасивната реченица, а кај овие ПП во самата активна реченица субјектниот аргумент е носител на семантичката улога трпител (на пр. Пол во Paul took a kick from John). Второ, синтаксичката пасивизација овозможува редукција на агенсот, но кај овие ПП агенсот може да се редуцира и во активната реченица (како во 15a).

Во поглед на категоријата определеност, номинализацијата во состав на ПП е најчесто неопределена, но може да се реализира како определена именка, со што од компонента на ПП прераснува во вистински аргумент во позиција на ДО. Така, во примерот (31) се работи за некој конкретен удар за кој веќе претходно станало збор во контекстот, и на овој начин, показателот за определеност во ПП придонесува за кохезијата на текстот.

$$
\begin{aligned}
& \text { I... had sat down when we took the hit. (БНК) } \\
& \text { 'Само што седнав, го примивме ударот.' }
\end{aligned}
$$

Евидентирани се и примери на релативизација на именката од ПП преку глаголската компонента на ПП, како во (32): 
I was given some advice about you - advice which I took against my better judgment, but it seems that advice was wrong. (БНК)

'Ми дадоа совет во врска со тебе - совет што го прифатив наспроти својот здрав разум, но се чини дека тој совет беше погрешен.'

Во поглед на збороредот, кај овие ПП вообичаено доминира неутралниот збороред $\mathrm{C}+\mathrm{C} Г+Д О$, но постојат и примери со маркиран збороред. Таков е примерот (33a), во кој ИС this advice се топикализира точно заради тоа што содржината на советот претходи во дискурсот. Од истата причина употребата на (33б) не би била најсоодветна, иако оваа реченица е граматички сосема точна. Блискозначна парафраза со АГ не постои зашто со АГ е невозможно да се постигне ефектот на алтернативна комуникациска хиерархија на аргументите.

a. In 1959, when I visited America and had the chance to talk about all this with Frank Buchman, he said firmly to me, "You won't go back to Africa until you are fundamentally different, so different that no one recognises you." This advice I took seriously; and Myra and I spent the next ten years mostly in Britain. (БНК)

'Во 1959 година, кога ја посетив Америка и имав можност да поразговарам за сето ова со Френк Бучман, тој одлучно ми рече: „Нема да се вратиш во Африка додека сосема не се промениш, толку да се промениш што никој нема да те препознае.“ Овој совет сериозно го прифатив и со Мајра ги поминавме следните десет години главно во Велика Британија.'

б. ... I took this advice seriously.

'...jас сериозно го прифатив овој совет.'

Од сето она што беше изнесено во 4.1 и во 4.2 може да се заклучи дека некои особини на ПП со take укажуваат на граматикализација. ${ }^{6}$ Прво, во однос на аспектуалноста, видовме дека ПП со take можат да воспостават видска опозиција со АГ. Исто така, за разлика од АГ, кај некои од ПП co take

\footnotetext{
${ }^{6}$ Меѓу особеностите кои укажуваат на граматикализација кај ПП со СГ make, take, give, have и $d o$, кои типично имаат неопределен член пред именката, Бринтон (Brinton 2011) ги наведува следниве: висока продуктивност (постојано проширување на репертоарот на девербативни именки кои се комбинираат со овие СГ), релативна транспарентност на значењето, а најзначајна е нивната семантичко-прагматичка експанзија. Ова значи дека како резултат на присуството на неопределениот член, конструкцијата се збогатува со значење на теличност, која го надополнува процесуалното значење. Ваквото значење не е присутно во соодветниот полнозначен глагол. Во случај на понатамошна граматикализација на овие конструкции, може да се очекува СГ да се развива во насока на граматички (деривациски) префикс, слично како што и во словенските јазици префиксите изразуваат видско значење (Brinton 2011: 568).
} 
забележлива е инхоативната компонента, која се должи на СГ take. Потоа, овие ПП се семантички доста транспарентни, а моделот е продуктивен. Од приложените примери од БНК, може да се согледа дека ПП co take покажуваат извесна синтаксичка флексибилност со тоа што дозволуваат придавска модификација (took a deep sniff, took a long look, took an instant dislike) или показател за определеност на именската компонента во ПП (the Scots took the lead on the stroke of half-time), но за повеќето ПП со take не е вообичаена пасивизацијата. Сепак, сите ПП со take не се однесуваат на ист начин во поглед на граматикализацијата.

\section{3 Квантитативна анализа}

Во овој дел може да се проследи во колкава мера мотивација за употребата на ПП биле можноста за пасивизација и можностите за определеност и квантификација на именката во ПП.

Меѓу анализираните примери од корпусот доминираат оние со ПП во активна дијатеза, со вкупна застапеност од $83 \%$. Нешто повеќе од половина од ПП во активна дијатеза се во простото минато време и се употребени за изразување на завршени дејства кои се случиле во минатото, за што секако придонесува иманентно перфективниот карактер на take. Потоа, доста е застапено и простото сегашно време (20\% од ПП во активна дијатеза) за изразување на омнитемпоралност, хабитуалност или историски презент. Трајните времиња се јавуваат многу ретко $(7 \%)$ и тоа обично со ПП кои означуваат краткотрајни, а не моментални дејства. Што се однесува на перфектните времиња, тие се застапени со $15 \%$, а со нив најчесто се изразуваат завршени минати дејства во неодреден момент во минатото. Впечатливо е тоа што за некои ПП со take примерите во пасивна дијатеза беа помногубројни отколку оние во активна дијатеза, како што беше случај со ПП take a decision. Тоа се должи, пред сѐ, на фактот што со пасивизацијата се овозможува редукција на агенсот.

Што се однесува на категориите определеност и број, забележавме дека ИС во состав на ПП со take во примерите од БНК се јавува во четири поттипа: неопределена именка во еднина (we shall be taking a look at some of these unfortunate happenings), определена именка во еднина (the Scots took the lead on the stroke of half-time), неопределена именка во множина (theytake decisions and control factors of production), и определена именка во множина (they still do the bulk of the domestic work and men take the important decisions).

Големо мнозинство од примерите се со неопределена именка во еднина (75\%). Следниве фактори се вбројуваат во причините за употребата на ПП со неопределена именка во еднина: воспоставувањето на видска опозиција со АГ, инхоативноста, семантичките разлики меѓу ПП и АГ, редукцијата на аргументите, и сл. ПП со определена именка во еднина се поретко застапени 
$(17 \%)$ и за нив може да се каже дека токму показателот за определеност ја мотивира употребата на ПП во однос на АГ. ПП со именка во множина има околу 8\%, и кај нив мотивацијата за употреба е квантификацијата на именката.

\section{5 Заклучок}

ПП co take ce семантички доста разнородни, заради што се анализираат во четири различни групи. За ПП од Група 1 и 2 заедничко е тоа што агенсот е истовремено и примател, а разликата се состои во тоа што ПП од Група 1 се однесуваат на дејства на сетилна перцепција, а ПП од Група 2 означуваат (најчесто) физичко дејство кое се врши за корист/благосостојба на агенсот. Кај ПП од Група 3 физичката енергија се насочува од агенсот и кон планираниот примател, но не мора задолжително да биде постигната целта, додека ПП од Група 4 претставуваат примери за лексичка пасивизација бидејќи во нив се тргнува од перспективата на трпниот примател, т.е. примателот на физичката енергија. Во овој контекст, Графиконот 1 ги сумира метафоричките проширувања на прототипското take во ПП од групите 1-4.

Некои ПП co take воспоставуваат антонимен однос со ПП co give. Меѓутоа, ова не важи ниту за ПП од Група 2, кои имаат само еден партиципант, ниту за ПП од Група 3 во кои физичката енергија се насочува $o g$ агенсот. Практично, релациската антонимија се согледува само меѓу ПП co give и ПП co take од Група 4, бидејќи кај нив текот на физичката енергија е обратно насочен во однос на референтот во позиција на субјект. Имено, кај ПП со take енергијата е насочена кон референтот во позиција на субјект (трпен примател), но кај ПП со give енергијата е насочена og референтот во позиција на субјект (агенс).

Во однос на хипотезите поставени во Воведот, би можело да се констатира дека не секогаш меѓу ПП со take и соодветниот АГ може да се воспостави релација на синонимија. Врз основа на примерите се утврди дека ПП co take овозможуваат да се воспостави видска опозиција со соодветниот АГ бидејќи кај ПП дејството генерално се сфаќа како завршено и комплетно реализирано, а кај некои ПП се потенцира инхоативноста. Овие особини на ПП co take не можат да се изразат само со АГ и овде веројатно лежи и главната мотивација за постоењето на овие ПП. Освен тоа, за употребата на ПП со take секако придонесуваат и другите стандардни предности на ПП, како што се можностите за определеност кај именката, за квантификација, за придавска модификација, и сл. Земајќи ги предвид сите овие карактеристики, би можело да се заклучи и дека ПП со take овозможуваат попрецизно изразување во однос на соодветниот АГ. 


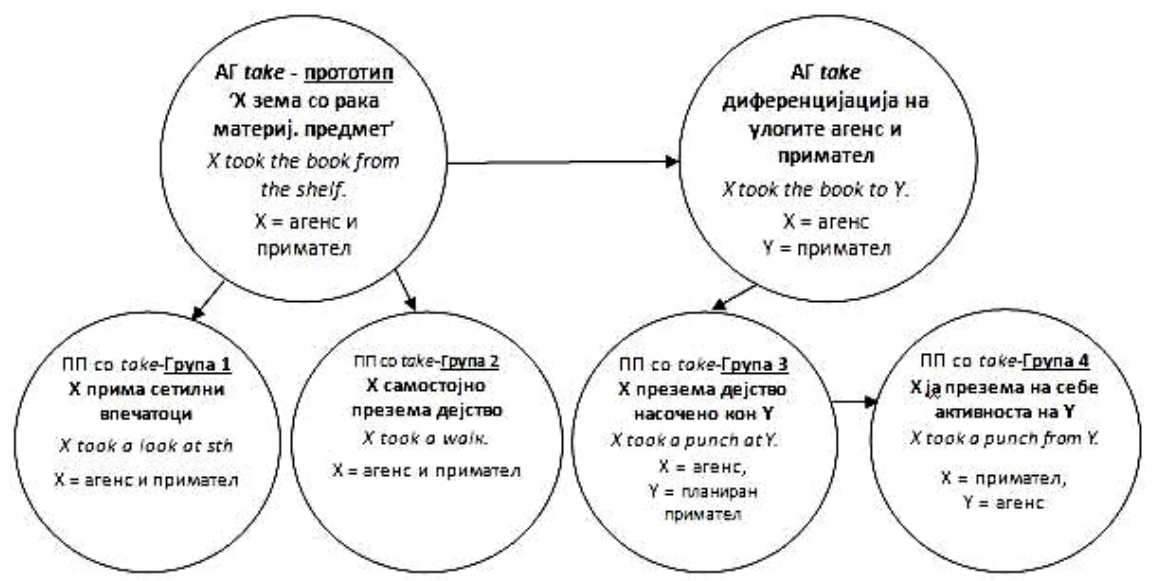

Графикон 1. Графички приказ на метафоричките проширувања на СГ во ПП со take

\section{Библиографија}

Algeo, J. (2006). British or American English: A handbook of word and grammar patterns. Cambridge: Cambridge University Press.

Allerton, D. J. (2002). Stretched verb constructions in English. London: Routledge.

Benson, M., Benson, E. and Ilson, R. (1986). The BBI combinatory dictionary of English: A guide to English word combinations. Amsterdam: John Benjamins.

Brinton, L. J. (2011). The grammaticalization of complex predicates. In B. Heine and H. Narrog (eds.), The Oxford Handbook of Grammaticalization, 559-569. Oxford: OUP.

Brinton, L. J. (1996). Attitudes toward increasing segmentalization: Complex and phrasal verbs in English. Journal of English Linguistics, 24: 186-205.

Brugman C. (2001). Light verbs and polysemy. Language Sciences, 23: 551-78.

Crowther, J.; Dignen, S. and Lea D. (eds.). (2002). Oxford collocations dictionary for students of English. Oxford: Oxford University Press.

Crystal, D. (2008). A dictionary of linguistics and phonetics-sixth edn. Oxford: Blackwell Publishing.

Curme, G.O. (1935). A grammar of the English language, Vol.2. Boston: D.C. Heath and Company.

Dixon R.M.W. (2005). A semantic approach to English grammar (Second edition). Oxford : Oxford University Press.

Gradečak-Erdeljić, T. (2009). Proces shematizacije engleskih laganih glagola. Jezikoslovlje. 10, 2: 95-131.

Hill, J. and Lewis, M. (eds.) (1997). LTP dictionary of selected collocations. Hove: Language Teaching Publications.

Hurford, J.R and Heasley, B. (2007). Semantics: A coursebook (Second edition). Cambridge: Cambridge University Press.

Jespersen, O. (1942). A modern English grammar on historical principles, Part VI, Morphology. London: George Allen and Unwin Ltd. 
Koptjevsksaja-Tamm, M. (1993). Nominalizations. London: Routledge.

Newman J. (1996). Give - A cognitive linguistic study. Berlin: Mouton de Gruyter.

Norvig, P. and Lakoff, G. (1987). Taking: A study in lexical network theory. In Proceedings of the Thirteenth Annual Meeting of the Berkeley Linguistics Society, 195-206. Berkeley: Berkeley Linguistics Society.

Poutsma, H. (1926). A grammar of late modern English, Part 2: The parts of speech. Groningen: P. Noordhoff.

Quirk, R., Greenbaum, S., Leech G. and Svartvik, J. (1985). A comprehensive grammar of the English language. London: Longman.

Stein, G. (1991). The Phrasal Verb Type 'to have a look' in Modern English. IRAL, Vol. 29: 1-29.

Wierzbicka, A. (1982). Why you can have a drink when you can't *have an eat. Language 58: 753-799.

Бужаровска, Е. (2013). Глаг̄оли за ауgийивна иеерцейција - семанӣика и синйакса. Скопје: Филолошки факултет „Блаже Конески“.

Миркуловска, М. (1991). Перифрастиични ӣреgикайи у макеgонском језику и њихови йољски еквиваленйи. Магистерски труд. Београд: Филолошки факултет.

Тополињска, 3. (1982). Перифрастични предикатски изрази на међусловенскким релацијама. Јужнословенски филолог̄ XXXVIII, 35-49. Београд: Институт за српскохрватски језик.

Тополињска, 3. (2003). Полски - макеgонски: Грамайичка конфронйащија. 6. Синйаксичка gеривација. Скопје: МАНУ. 